\title{
Discrete Set Data Type
}

National Cancer Institute

\section{Source}

National Cancer Institute. Discrete Set Data Type. NCI Thesaurus. Code C95646.

A data type comprised of a collection of values that are distinct and discrete. 